\title{
Before China: Dunhuang, Turfan and Tibet
}

At the beginning of the eleventh century, the Qarakhanid roads to China passed through Dunhuang, which was located at the western edge of the Hexi Corridor in China's present-day Gansu Province. ${ }^{1}$ This is not unexpected, as Dunhuang had been the main entry point to China from Central Asia since ancient times. However, it is believed that due to the Song conflicts with the Khitans and the Tanguts Dunhuang lost its significance along the overland Silk Roads after the mid-tenth century and never regained it. ${ }^{2}$ Conversely, this study demonstrates that Dunhuang continued to play an important role along the overland Silk Roads connecting China with the West in the tenth-eleventh centuries. It was known at this time as Shazhou in Chinese sources and was indicated as Shānjū in the Qarakhanid world map. ${ }^{3}$

Qarakhanid delegations apparently had to pass through Turfan, which was under the rule of the Uyghur Idiquts, to arrive in the Khitan realm. The same road was used by the Khitan delegation that arrived in the Gahznavid court in 1026/1027 and by Yelü Dashi, the founder of the Qara Khitai dynasty during his journey to the west. Both had to cross Turfan to reach the Qarakhanid realm. Chinese and Central Asian sources provide very limited information on Qarakahnaid possible contacts with the Xizhou Uyghurs, and this chapter seeks to combine all available data.

It should be also pointed out that Qarakhanid envoys and merchants had an alternative road to Song China via Tibet, avoiding the passage along the Hexi Corridor. This road was actively used during the second half of the eleventh century, especially, when the Tanguts sought to monopolize roads that connected Central Asia with China.

Țabāit al-hayawān, ed. and trans. Minorsky, 18, *6.

2 Rong, Eighteen Lectures, 76.

3 For the facsimile of the map, see Dìwān lughāt al-Turk, trans. Auezova, 1289-129o. 


\section{$2 \quad$ Dunhuang}

The road from Khotan and Kashghar to Dunhuang took 55 and 69 days, respectively. ${ }^{4}$ The first Qarakhanid delegation that arrived in Song China in 1009 described the road between Khotan and Dunhuang, pointing out that the road was safe and peaceful. ${ }^{5}$ The Qarakhanid envoy that arrived in Kaifeng in 1081 also mentioned territories they passed on their way. This itinerary was recorded in Chinese sources. The envoy informed that they came via the Tsongkha kingdom. Describing the territory between the Khotan and the Tsongkha regions, he did not mention the Tanguts, but instead provided information on territories of "the Yellow-Head Uyghurs" and "the Straw-Head Tatars;" the latter were located near Hexi (Gansu) and Tiande (Bayannur) during the Tang period. ${ }^{6}$ The exact locations of these groups in the eleventh century are uncertain. There are two possible sites. The envoy could arrive via the Hexi Corridor Road or the Qinghai Road.

The first road was used by the Qarakhanids in the beginning of the eleventh century. However, the itinerary between the Qarakhanid Khaganate and the Tsongkha kingdom provided by the Qarakhanid envoy in 1081 most likely referred to the Qinghai Road. When Emperor Shenzong asked the Qarakhanid envoy about the location of the Straw-Head Tatars who previously lived between Bayannur and Gansu, he answered that the Tatars lived scattered. They were also mentioned as "sworn enemies" of the Tanguts. ${ }^{7}$ Therefore, the emperor ordered to draw a map of territories between the Tatars and Song China. This map was used by the Song envoy, who was sent to the Tatar realm via the Tsongkha kingdom. It can be assumed that some Tatar groups moved from their previous territories to the new location, which was not in Gansu. ${ }^{8}$ The territory of the Yellow-Head Uyghurs was mentioned after the Tatar realm. This means that the Tatars and the Uyghurs mentioned by the Qarakhanid envoy between Khotan and Qingtang, the capital of the Tsongkha kingdom, were located in the Qinghai region during the second half of the eleventh century. They probably were forced to leave their previous territories in Gansu due to the Tangut conquest.

4 Ṭabā'i al-ḥayawān, ed. and trans. Minorsky, 18, *6.

5 Song shi, 490: 14107.

6 Xu zizhi tongjian changbian, 335: 8o61; Song shi, 49o: 14109; Song huiyao jigao, Fanyi 4: 17. Duturaeva, "Qarakhanid Envoys," 190.

7 Xu zizhi tongjian changbian, 335: 8061 .

8 Xu zhizhi tongjian changbian, 335: 8063; Song huiyao jigao, Fanyi 4: 17. 
However, the road via Dunhuang was important to initiate contact with Song China. Who were the Qarakhanids partners in Dunhuang? After the fall of the Uyghur Khaganate in 840, some Uyghur groups migrated westward. One part settled in the Turfan Basin and formed the Uyghur Khaganate known in Chinese sources as the Xizhou Uyghurs, which lasted until the mid-fourteenth century. Another part arrived in Ganzhou and neighboring territories in the Hexi Corridor and created the Uyghur Khaganate of Ganzhou known in Chinese sources as the Ganzhou Uyghurs, which was destroyed by the Tanguts in 103 os.

The Shazhou Uyghurs sent envoys to Song China starting in the tenth century. For instance, Song sources recorded that the Ganzhou, Shazhou, and Guazhou Uyghurs sent a joint delegation to the court in 966..$^{9}$ The ruler of the Ganzhou Uyghurs was also mentioned as the Kaghan of the Ganzhou and Shazhou Uyghurs. ${ }^{10}$ It demonstrates that Dunhuang was occasionally under the control of the Ganzhou Uyghurs. However, Uyghur and other Turkic groups started to settle in Dunhuang even earlier. Some groups of Ganzhou Uyghurs likely also remained in Dunhuang when the Tanguts destroyed their polity. Later these Uyghurs continued to be known jointly in Chinese sources as the Shazhou Uyghurs and regularly sent envoys to the Song court in the eleventh century. However, the creation of the Khaganate by the Shazhou Uyghurs is doubtful. ${ }^{11}$ In fact, from the middle of the ninth to the early eleventh centuries, Dunhuang was under Guiyijun rule, which was initially a military outpost set up by the Tang in 851 and later became an independent polity viewed as a foreign country during the Song period. ${ }^{12}$ The Song official history included the records of Dunhuang to the section devoted to Central Asia, Iran, India, Arabia, and Asia Minor:

沙州本漢燉煌故地, 唐天寶末陷于西戎。大中五年, 張義潮以州歸 順, 詔建沙州為歸義軍, 以義潮為節度使, 領河沙甘肅伊西等州觀 察、營田處置使。義潮入朝, 以從子淮深領州事。至朱梁時, 張氏之 後絕, 州人推長史曹義金為帥。義金卒, 子元忠嗣。周顯德二年來 貢，授本軍節度、檢校太尉、同中書門下平章事，鑄印賜之。

建隆三年加兼中書令, 子延恭為瓜州防禦使。興國五年元忠卒, 子 延祿遣人來貢。贈元忠燉煌郡王, 授延祿本軍節度, 弟延晟為瓜州刺

9 Song shi, 490: 14114; Song huiyao jigao, Fanyi 4: 2; 7: 3.

10 Song shi, 490: 14114.

11 For the discussion on the concept of "Uyghur Khaganate of Shazhou," see Rong, Eighteen Lectures, 326 .

12 Ibid, 40-41. 
史, 延瑞為衙內都虞候。咸平四年, 封延祿為譙郡王。五年, 延祿、 延瑞為從子宗壽所害, 宗壽權知留後, 而以其弟宗允權知瓜州。表求 旅節, 乃授宗壽節度使, 宗允檢校尚書左僕射、知瓜州, 宗壽子賢順 為衙內都指揮使。大中祥符末宗壽卒, 授賢順本軍節度, 弟延惠為檢 校刑部尚書、知瓜州。賢順表乞金字藏經洎茶藥金箔, 詔賜之。至天 聖初, 遣使來謝, 貢乳香、砬砂、玉團。自景祐至皇祐中, 凡七貢 方物。13

Shazhou was originally the old place of the Han called Dunhuang and at the end of the Tianbao era [742-756], fell into the Xirong. ${ }^{14}$ In the fifth year of the Dazhong era [851], Zhang Yichao annexed and conquered this prefecture; the Emperor ordered to establish Shazhou as Guiyijun and made Zhang Yichao jiedushi [Regional Military Commissioner], guancha [Investigating Commissioner] of Hezhou, Shazhou, Ganzhou, Suzhou, Yizhou and Xizhou and chuzhishi [Commissioner] of Yingtian. ${ }^{15}$ When Zhang Yichao went to the court, his nephew Zhang Huaishen was put in charge of the prefecture's affairs. By the time of the Zhu Liang period, the Zhang dynasty was discontinued and the people of Shazhou recommended zhangshi [Aide] Cao Yijin to become governor. When Cao Yijin died, his son, Cao Yuanzhong, succeeded him. In the second year of the Zhou Xiande era [955] he came to offer tribute. He was given the posts of junjiedu [Military Commissioner], jianjiao taiwei [Acting Defender-in-Chief], and zhongshu menxia pingzhang shi [Joint Manager of Affairs with the Secretariat-Chancellery], and was granted the official seal.

In the third year of the Jianlong era [962], he also held the post of the zhongshuling [Head of the Secretariat] and his son Cao Yangong became the fangyushi [Defense Commissioner] of Guazhou. In the fifth year of the Xingguo era [980] Cao Yuanzhong died and his son Cao Yanlu sent people to offer tribute. The Emperor bestowed upon Cao Yuanzhong the honorary title after death junwang [Commander Prince] of Dunhuang and gave Cao Yuanlu the post of the junjiedu [Military Commissioner] of this prefecture, his younger brother Cao Yansheng became cishi [Regional Chief] of Guazhou and Cao Yanrui became yanei du yuhou [Inspector-in-Chief of Palace Guards]. In the fourth year of the Xianping

13 Song shi, 490: 14123-14124.

14 "Xirong" is an ancient name for non-Chinese peoples in the west.

15 Yingtian was a popular land system of military cultivation in frontier regions during the Tang and Song dynasties. 
era [1001], Cao Yuanlu was given the title junwang of Qiao. In the fifth year of the Xianping era [1002], Cao Yanlu and Cao Yanrui were killed by their nephew Cao Zongshou, who held the position of quanzhi liuhou [Deputy Commander] and appointed his younger brother Cao Zongyun as quanzhi of Guazhou. He sent a memorial to the Emperor and requested an insignia; the Emperor gave Cao Zongshou the post of jiedushi [Military Commissioner], and Cao Zongyun the post of jianjiao shangshu zuo pushe [Acting Vice Director of the Left of the Department of State Affairs] and made him in charge of Guazhou. Cao Xianshun, Cao Zongshou's son, became yanei duzhihuishi [Commander-in-Chief of Palace Guards]. At the end of the Dazhongxianfu era [1008-1016] Cao Zongshou died and the Emperor gave Cao Xianshun the post of junjiedu; his brother Cao Yanhui became jianjiao xingbushangshu [Acting Ministry of the Department of State Affairs] and was in charge of Guazhou. Cao Xianshun sent a memorial and requested the Buddhist Canon with gold characters, tea, medicine and gold leaf, it was ordered that it all be granted. By the beginning of the Tiansheng era [1023] he sent an envoy to offer thanks along with frankincense, ammonium chloride, and jade lumps. From the Jingyou era [1034-1038] to the middle of the Huangyou era [1049-1054] he offered local products to the court seven times altogether.

This Chinese text does not mention the presence of the Uyghurs in Dunhuang. The official control was indeed in the hand of the Guiyijun, at least until the middle of the eleventh century. At the same time, due to its geographical location, Dunhuang was always a cosmopolitan region. Dunhuang texts and documents in Chinese, Tibetan, Khotanese, Sogdian, Uyghur, Syriac and Sanskrit dated to 850-100o may serve as the best demonstration of the existence of multilingual society in Dunhuang at this time. ${ }^{16}$ For instance, the Sogdian community was one of the largest foreign groups living in Dunhuang. They started to settle in this region during the Tang period and remained there until the Song era. Imre Galambos pointed out that despite being largely sinicized, some Sogdians might have been bilingual and remained literate in both Chinese and Sogdian. ${ }^{17}$ Rong Xinjiang even proposed that the Cao family, who ruled in Dunhuang during the Guiyijun period, might have been of Sogdian origin. ${ }^{18}$

16 Rong, Eighteen Lectures, 72-75; Imre Galambos, "She Association Circulars from Dunhuang," in A History of Chinese Letters and Epistolary Culture, ed. Antje Richter (Leiden-Boston: Brill, 2015), 871.

17 Galambos, "She Association Circulars," 873.

18 Rong, Eighteen Lectures, 331. 
Cao was the Chinese name of the Sogdian city-state Kaputana. Ushrusana was known as Eastern Cao and Ishitikhan as Western Cao. Sogdians from these places who settled in China during the Sui-Tang period were known by this name. Therefore, the Cao family that ruled in Dunhuang was most likely of Sogdian origin.

The Guiyijun regime of Dunhuang established mutual diplomatic, trade and cultural links with the Ganzhou Uyghurs and the Xizhou Uyghurs, strengthened with marriage alliances. ${ }^{19}$ The text from Song shi quoted above mentions diplomatic gifts from the Dunhunag ruler sent to Song China in $1023 .{ }^{20}$ The presence of frankincense and jade among these gifts allows us to draw conclusions about trade relations between the Cao family and the Qarakhanids. In fact, frankincense appeared among the Dunhuang gifts sent to China starting in 1007..$^{21}$ The jade trade was also under the Qarakhanid control after the conquest of Khotan. Therefore, it can be assumed that the Qarakhanids definitely had diplomatic and trade relations with the Guiyijun in Dunhuang no later than the early eleventh century.

In 103os Dunhuang, as well as other regions located in the Hexi Corridor, started to be incorporated into the Tangut Empire and the Guiyijun regime began to lose its power. However, it seems that the level of Tangut control varied over the years. Especially in the initial stage of the Tangut Empire. During a short period of time, the Shazhou Uyghurs were also connected with the Xizhou Uyghurs. ${ }^{22}$ For instance, Dunhuang scholars have observed that some paintings in the Mogao caves in Dunhuang are similar to the artistic style of the Xizhou Uyghurs shown in the Bezeklik caves. ${ }^{23}$ Moreover, Lilla Russel-Smith pointed out that Uyghur clothing depicted in the Mogao caves in Dunhuang is comparable to the Uyghur rulers shown in the Bezeklik caves in Turfan, and the presence of these large portraits demonstrates the Uyghur political dominance

19 For marriage alliances between the Uyghurs and the Guiyijun regime in Dunhuang, see Lilla Russel-Smith, Uygur Patronage in Dunhuang: Regional Art Centers on the Northern Silk Road in the Tenth and Eleventh Centuries (Leiden-Boston: Brill, 2005), 58-68.

20 Song shi, 490: 14124.

21 See Chapter 6.

22 Takao Moriyasu, "The West Uighur and Tun-huang around the 10th-11th centuries," Berichte und Abhandlungen der Berlin-Brandenburgische Akademie der Wissenschaften, Band 8 (Berlin: Akademie Verlag, 200o), 348; Horlemann, "The Relations of the EleventhCentury Tsong Kha," go.

23 Liu Yuquan 刘玉权, “Guanyu Shazhou Huigu dongku huafen (zhaiyao) 关于沙州回 鹘洞窟的划分(摘要) [About the Division of the Shazhou Huigu Cave (Abstract)], Dunhuang yanjiu 敦煌研究 2 (1988): 9-11; Russel-Smith, Uygur Patronage in Dunhuang, $69-75$. 
in Dunhuang during the Tanguts rule in the Hexi Corridor. ${ }^{24}$ However, the Tanguts obviously sought to control the Dunhuang passageway that frequently caused conflicts with the Qarakhanids. Therefore, the Qarakhanids attacked the Tanguts in Dunhuang and neighboring territories in 109os. ${ }^{25}$ It demonstrates that Dunhuang and the Hexi Corridor Road continued to be important for the Qarakhanids and they did not want to lose access to this passage to China.

It can be concluded that the Tangut conflicts with the Song and the Khitans in the eleventh century did not allow them to control Dunhuang entirely, giving the Uyghurs de facto independence. The fact that the Uyghurs were portrayed in Dunhuang in the style of the Uyghur royal portrait tradition also confirms their dominance. ${ }^{26}$ Starting from the end of the eleventh century, the Tanguts worked on strengthening their positions in the Hexi Corridor including in Dunhuang. This caused a military conflict with the Qarakhanids, who even requested assistance from the Song in $1093 .{ }^{27}$ The situation changed in the twelfth century when the Tanguts signed a peace treaty with the Song and established diplomatic relations with their neighbors in the east and the west, the Jurchens and the Qara Khitai. Qarakhanid envoys and merchants were no longer mentioned in Chinese sources during the Southern Song period. It can be connected with political changes in Qarakhanid realm that became a subject of the Qara Khitai. Qarakhanid merchants probably continued to be involved in international trade in the east, but it is not known how distant their trade in China was.

\section{3} Turfan

The Uyghur polity in Turfan known in Chinese sources as Xizhou was depicted on the Qarakhanid world map as the Uyghur land (biläd Uyghur) with its capital Qocho (Qūjū). It was most likely the Uyghur Khagan of Turfan who dispatched an envoy jointly with the Khitan delegation that arrived in the court of Sultan Mahmud of Ghazna. ${ }^{28}$ However, Vladimir Minorsky suggested that it might be the Ganzhou Uyghurs. He pointed out that in the case of the Xizhou Uyghurs it would be strange that the ruler did not use his honorable title

\footnotetext{
24 Russel-Smith, Uygur Patronage in Dunhuang, 69-70.

25 Song shi, 490: 14109.

26 Russel-Smith, Uygur Patronage in Dunhuang, 70.

27 Song shi, 490: 14109.

28 For the discussion on the Uyghurs in the Marwazi's account, see Chou Yi-liang, "Notes on Marvazi's Account on China," Harvard Journal of Asiatic Studies 9, no. 1 (1945): 19-21.
} 
"Idiqut" in the official letter. He also assumed that the Khitans attached more importance to the Ganzhou Uyghurs than to the Xizhou Uyghurs because the Khitan emperors adopted a patronizing attitude towards them. ${ }^{29}$ On the other hand, Marwazī, who recorded the joint Khitan-Uyghur mission to Ghazna, provided a translation of the letter that might differ from the original, and his description of the Uyghur territory clearly refers to Turfan. For instance, he recorded that a traveler should turn towards the left after passing Dunhuang in order to reach Qocho, a city of the Uyghur Khagan (Yughur Khan). The road to Ganzhou (Qāmjū ) was described as an opposite direction towards the southeast that located on the way to Song China (al-Ṣin).$^{30}$ Chinese sources recorded more envoys and exchanges between the Khitans and the Xizhou Uyghurs, especially compared to the number of delegations sent by the Ganzhou Uyghurs to the Khitans. It can be observed that the Ganzhou Uyghurs were looking more towards developing their relations with Song China. Therefore, it was most likely the Xizhou Uyghurs who joined the Khitan mission to Ghazna.

The Uyghur Khagan pointed out in his official letter to Sultan Mahmud of Ghazna that the road of the Khitan envoy laid through his territory. ${ }^{31}$ If we accept that the Uyghur Idiquts dispatched this mission then it means that Qarakhanid delegations crossed Turfan on the way to Liao China and therefore had to initiate diplomatic contacts with the Xizhou Uyghurs in order to access the Khitan territory. There are several facts and sources that prove the relationship between the Qarakhanids and the Xizhou Uyghurs.

Yutaka Yoshida has recently published an article on Manichaean Sogdian letters found in Turfan that demonstrates commodity transportation from Transoxiana to Turfan and regular correspondence exchange between Manicheans of Samarqand and Turfan in the tenth and early eleventh centuries. For instance, one of these letters was sent in the early eleventh century by a bishop of the Manichean community located near Samarqand to celebrate the New Year and addressed to the "Teacher Aryāmān Puhr in Turfan."32 It is not clear whether these letters were brought directly by the Manichean monks that might be traveling between Samarqand and Turfan or arrived via other links. However, this kind of document definitely proves the existence of networks and contacts between territories of Turfan and Samanid/Qarakhanid

29 Țabä’’ al-hayawān, ed. and trans. Minorsky, $77-78$.

$30 \quad$ Ibid, 18 , Arabic text, ${ }^{*} 6$.

31 Ibid, 21, Arabic text, ${ }^{*} 7$.

32 For the documents, see Yutaka Yoshida, "Relation Between Sogdiana and Turfan During the 1oth-11th Centuries as Reflected in Manichaean Sogdian Texts," Journal of the International Silk Road Studies 1 (2017): 113-25. 
Transoxiana. For instance, the Song envoy Wang Yande, who visited Turfan in 982-983, mentioned Persian monks living there:

復有摩尼寺，波斯僧各持其法，佛經所謂外道者也。33

There is also a Manichean temple and all Bosi [Persian] monks follow its doctrine, it is called waidao ["outside road," non-Buddhist] in the Buddhist texts.

These Manichean monks could have been from Transoxiana and Khurasan. Manichaeans from these regions were moving to the East due to the expansion of Islam in the Khurasan-Afghanistan-Transoxianian region. Wang Yande also recorded neighboring territories of Turfan. Khotan was located in the west of the country. This means that the Qarakhanids shared the common borders with the Xizhou Uyghurs after the Khotan conquest:

高昌即西州也。其地南距于闐, 西南距大食、波斯, 西距西天步路 涉、雪山、苞嶺, 皆數千里。34

Gaochang is Xizhou. In the south, its territory reaches Yutian [Khotan], in the southwest it reaches Dashi and Bosi, in the west it reaches Xitian Bulushe [Indian Purushapura], Xueshan [Snow Mountains, i.e. the Himalayas] and Congling [Pamir], they all are several thousand $l i$ apart.

In this passage, Yutian refers to the Khotan kingdom that was later conquered by the Qarakhanids. Dashi might refer either to the Qarakhanids or the Samanids during this period but it could be also applied to both polities, meaning the Muslim territory more generally. Bosi, which is translated as Persia, may refer to the Samanids, but also to the Ghaznavids. For instance, the Chinese recorded an envoy from Bosi located in Northern India that arrived in Kaifeng in 984. The Persian state in Northern India and its association with the Ghaznavids are discussed in Chapter 5 .

The Qarakhanid presence in the East before the Khotan conquest can be confirmed mainly by commodities that circulated in the region. Before it, there was no specific name used to refer to the Qarakhanids. They might appear under the general name "Tujue" during the pre-Islamic period and later under the term "Dashi." Therefore, it is not always possible to identify

33 Song shi, 49o: 14112.

34 Ibid, 49o: 14111. 
Qarakhanid delegations before they began to be associated with Khotan in China. However, it is generally accepted that "Dashi" mainly referred to the Qarakhanids in the Khitan and the Tangut sources. The earliest envoy from Dashi that may refer to the Qarakhanids was recorded in Liao sources in $924 .{ }^{35}$ According to Song sources, the Xizhou Uyghurs presented an amber cup to the Song emperor in $965 \cdot{ }^{36}$ Amber, mostly from the Baltic region, was transported by the Qarakhanids to the East. Archaeological data confirms the amber trade in Liao China in the tenth-eleventh century. Qarakhanid activity along the Amber Road was discussed in Chapter 6. Here it should be noted that despite the lack of written sources, we can still observe the presence of Qarakhanid commodities in the East starting in the tenth century.

It would seem that due to the shared borders, Qarakhanid sources should be more informative about contacts with Turfan. But contradictorily, there is not much data on this issue except information provided in the Tazkira-i Bughra Khān about a Qarakhanid attempt to conquer Turfan and convert the Uyghurs to Islam. ${ }^{37}$ In fact, it is also believed that this conflict between the Qarakhanids and the Uyghurs in Turfan was mentioned in Diwān lughāt alTurk as well, which described struggles between Muslims and the peoples of Minglaq, the territory of the Uyghurs. ${ }^{38}$

Fragments of fabrics produced in the Islamic world that were found in the Turfan region also confirm regular contact with Muslims, who might have mostly been from the Qarakhanid realm. ${ }^{39}$ Moreover, the Xizhou Uyghurs and the Qarakhanids became subjects of the Qara Khitai Empire in the twelfth century that connected trade roads between two territories. It seems that from the twelfth century onward, Qarakhanid merchants were not able to travel farther east regularly due to conflicts between the newly emerged Qara Khitai and

35 Liao shi, 2: 20.

36 Song shi, 490: 14110.

37 Eden, Warrior Saints, 45 .

38 Dìwān lughāt al-Turk, trans. Auezova, 917; Also see Peter Zieme, "Notes on the Religions in the Mongol Empire," in Islam and Tibet: Interactions along the Musk Routes, ed. Anna Akasoy, Charles Burnett, and Ronit Yoeli-Tlalim (Farnham: Ashgate, 2011), 183-184; Buayixiamu 布阿衣夏木, and Aji 阿吉, “Kalahan wangchao yu Gaochang Huigu hanguo zhengzhi guanxi 喀喇汗王朝与高昌回鹘汗国的政治关系探析 [Political relations between the Qarakhanid Dynasty and the Gaochang Uyghur Khaganate]," Ha'erbin xueyuan xuebao 哈尔滨学院学报 36, 12 (2015): 103 .

39 For Muslim textile in Turfan, see Kazuko Sakamoto, "Two Fragments of Luxury Cloths Discovered in Turfan: Evidence of Textile Circulation from West to East," in Turfan Revisited: The First Century of Research into the Arts and Cultures of the Silk Road, ed. Desmond Durkin-Meisterernst et al. (Berlin: Dietrich Reimer Verlag, 2014), 72-83, 297-302. 
Jurchen Empires. Therefore, the Turfan market played a significant role in the Qarakhanid economy, specifically during the Qara Khitai period.

At the beginning of the eleventh century, Qarakhanid missions came to China via Dunhuang, but the Qarakhanids stopped sending missions to Song China from 1025 to $1063 .{ }^{40}$ The Hexi Corridor was blocked by the Tanguts in this period and it probably also caused the interruption of Qarakhanid contact not only with the Song, but also with the Liao. Therefore, priority was given to finding alternative roads to Song China by establishing contact with the Uyghurs and the Tatars, who were enemies of the Tanguts. ${ }^{41}$ Tsongkha played a strategic role in Qarakhanid-Song relations during most of the eleventh century, offering a road to China via Tibet. Since the Tanguts had blocked existing routes, Qarakhanid envoys had their station at Tsongkha.

It is not known when exactly the Qarakhanids initiated diplomatic relations with Tsongkha and started to send their missions via Tibet. After the long hiatus, the Qarakhanids began to send envoys to China in $1063^{42}$ It is known that around 106o a chieftain from Xijie, the "Western realm," named Mangmi sent a delegation to the Tsongkha ruler Gusiluo presenting golden ware, brocades, and pack camels, and offered a marriage alliance. ${ }^{43}$ This may refer to the Qarakhanid delegation that arrived in China in 1063. Chinese sources confirm the Qarakhanid-Tsongkha relationship starting in the reign of Dongzhan $\left(1065^{-1083)}\right){ }^{44}$ Chinese chronicles also recorded that the mission that was dispatched in 1079 and arrived at the Song court in 1081 via Tsongkha, and was accompanied by the Tsongkha guide and interpreter. ${ }^{45}$ Moreover, Dongzhan married or took into service a woman from Khotan and adopted her son Aligu (1040-1096; reigned in 1083-1096), who became his successor. ${ }^{46}$ However, it is

40 Song shi, 490: 14108. Some materials used in this section were initially published in: Dilnoza Duturaeva, "From Turkistan to Tibet: The Qarakhanid Khaganate and the Tsongkha Kingdom," in The History and Culture of Iran and Central Asia: From the PreIslamic to the Islamic Period, ed. Deborah Tor and Minoru Inaba (Notre Dame: Notre Dame University Press, 2022), 305-327.

$41 \quad$ Xu zizhi tongjian changbian, 335: 8061.

42 Song shi, 490: 14108; Song huiyao jigao, Fanyi 7: 30-31.

43 Lequan ji, 22: 24a; Horlemann suggested that this mission could be sent from Kucha. Horlemann, "The Relations of the Eleventh-Century Tsong Kha," 99.

44 Wenchang zalu, 1: 2.

$45 \quad$ Xu Zizhi tongjian changbian, 314: 7612; Song shi, 490: 14109.

46 Song shi, 492: 1 4165; Horlemann, "The Relations of the Eleventh-Century Tsong Kha," 102. 
believed that she was one of the Khotanese refugees who migrated eastward after the conquest of Khotan by the Qarakhanids, rather than a member of the Qarakhanid dynasty. ${ }^{47}$ Chinese sources recorded around twelve missions from the Qarakhanids to the Song court during the reign of Dongzhan from 1083 to 1096.48 Most if not all of these missions were able to come exclusively via the Tsongkha kingdom. Qarakhanid envoys continued to flow to Tibet and China during the reign of the next Tsongkha ruler Aligu, who was Dongzhan's adopted son from Khotan as described above. During this period, Qarakhanid missions came almost annually, and sometimes two or three times a year. This demonstrates that Qarakhanid-Tsongkha relations intensified during the rule of Aligu.

Tsongkha rulers provided living quarters to Qarakhanid envoys. They could stay in the capital of Tsongkha for a year or more on their way to Song China. ${ }^{49}$ The reason for this extended residence in Tsongkha can be explained by economic interests from both sides. The Qarakhanids were not only allowed to cross Tsongkha, but also had permission to trade.

Tsongkha rulers provided Qarakhanid ambassadors with guides and interpreters, who accompanied them to China and served as translators for them and the Song emperors. They also translated written documents and messages sent by the Qarakhanid rulers to the Song court. Extracts of these documents were recorded in Song sources..$^{50}$ It can be assumed from similar forms of Qarakhanid and Tsongkha official letters sent to the Song court. For instance, the founder of the Tsongkha kingdom Gusiluo addressed the Song emperor as "Son of Heaven of the Zhao dynasty, the Lord of the East and my uncle."51 This is similar to the headings used in Qarakhanid letters. ${ }^{2}$ Both types of documents used the term ajiu to address the Song emperors. As I have discussed in Chapter 2, it is unlikely that the Qarakhanids used the term "maternal uncle" to refer to the Song emperors, because they did not have marriage alliances with the Song dynastic members, which was also pointed out by Central Asian authors. ${ }^{53}$ The Qarakhanids sought to establish marriage relations with the Liao dynasty and married Khitan princesses ${ }^{54}$ but there is no evidence

\footnotetext{
47 Rong, Eighteen Lectures, 132; Biran, "The Qarakhanids' Eastern Exchange," 58o.

48 For the list of Qarakhanid missions, see Appendix 3.

49 Xu Zizhi tongjian changbian, 335: 8o61; Song shi, 49o: 14109; Song huiyao jigao, Fanyi 4: 17.

50 Qingbo zazhi, 6: 52-53; Xu Zizhi tongjian changbian, 314: 7612; Song shi, 490: 14109. Full texts of Qarakhanid letters rarely depicted.

51 趙家天子及東君趙家阿舅. Qingbo zazhi, 6: 53 .

52 To compare with the Qarakhanids letters, see Document 4 in Appendix 2 and Chapter 2.

53 For instance, see Țabäं i' al-hayawān, ed. and trans. Minorsky, 15, for the Arabic text, see *3.

54 Liao shi, 16: 189; Țabä’’ al-ḩayawān, ed. and trans. Minorsky, 19.
} 
in Chinese or Muslim sources that can confirm royal marriages between the Qarakhanids and the Song emperors. The Tsongkha rulers simply applied the form used during the Tibetan Empire.

It is not clear why the Tsongkha ruler continued to use this form in official correspondence. It can be only assumed that Gusiluo, who according to Chinese sources was a descendant of the Tibetan imperial dynasty, wanted to emphasize the previous relationship and kinship between Chinese and Tibetan emperors. If we accept this assumption, then the Qarakhanids may also have applied this form referring to similar contacts between Tang China and the Uyghur Khaganate. This is even more plausible if we take into account a broader meaning of the Turkic term "uncle" and translation problems of Turkic kinship vocabulary in Chinese sources. Étienne de la Vaissière discussed the Chinese mistranslation of the Turkic term äçi meaning paternal uncle and elder brother, which could be used in a broader sense to refer to other elder male relatives on one's father's side. ${ }^{55}$ The Turkic term tagay, meaning "maternal uncle," can also refer to "maternal grandfather" or other elder male family members from one's mother's side. ${ }^{56}$ It means that the Qarakhanids could use this form in a broader sense even without marriage relations with the Song emperors.

It is difficult to determine what exactly the Qarakhanids offered to the Tsongkha rulers, as Chinese sources do not provide this information. From the list of gifts that Tsongkha rulers presented to Song emperors, however, it is possible to identify typical Qarakhanid commodities. For instance, the Tsongkha ruler Dongzhan presented pearls, frankincense, ivory, jade, and horses. ${ }^{57}$ Most of these items were probably obtained from the Qarakhanids, certainly the jade and frankincense. Tsongkha merchants most likely obtained the incense from the Qarakhanids and re-gifted it to the Song emperors. The Tsongkha ruler Aligu presented a lion to the Song emperor on April 21, 1094. ${ }^{58}$ He probably re-gifted the lion that was presented to him by the Qarakhanids. Items such as pearls and ivory began to be presented to the Song court during the Dongzhan period, which may indicate that these commodities were also obtained from the Qarakhanids. The Qarakhanids transported these rarities from Iran and India through their contacts with the Saljuqs and the Ghaznavids.

55 Étienne de la Vaissière, "Diadi i brat'ia: kagany Ashina i tiurskii slovar' rodstva," in Arkheologiia i istoriia Tsentral'noi Azii v trudakh frantsuzskikh uchenykh, ed. Shahin Mustafaev, and Henri-Paul Francfort (Samarkand: IICAS, 2014), vol. 2, 134-40.

56 Edgem R. Tenishev, ed., Sravnitel'no-istoricheskaia grammatika tiurkskikh iazykov: Leksika (Moscow: Nauka, 2001), 296.

57 Song shi, 492: 14164.

$5^{8}$ Ibid, 18: 340 . 
Tibetan musk was one of the main products that Qarakhanid merchants brought from Tsongkha. For instance, the Qarakhanid scholar Mahmūd al-Kāshgharī recorded information about Tibetan musk deer and musk production in Tibet. ${ }^{59}$ Musk was the most famous Tibetan product in the Islamic world and was incorporated into medicine and perfumery in early Islamic times. Tibetan musk first arrived in Sogdiana and India and then passed into the central parts of the Islamic world. ${ }^{60}$ Qarakhanid merchants continued this tradition and became the main suppliers of Tibetan musk in the Islamic world. Musk was also used as a diplomatic gift presented by Qarakhanid rulers to their neighbors in the Islamic world. ${ }^{61}$

The Qarakhanid merchants were also involved in the tea trade with Tsongkha. It is known that Tsongkha was one of the main suppliers of horses for Song China. They exchanged horses and sheep mainly for Chinese tea and silk. ${ }^{62}$ Trade roads known as "the Ancient Tea Horse Road" had connected southwest China and Tibet since the Tang period and flourished during the Song. Tibet supplied horses in exchange for Chinese tea, which became a staple of their diet. The tea trade between China and Tibet flourished during the Song period. The rulers of the Tsongkha kingdom sent envoys presenting sheep and horses for Chinese tea and silk. ${ }^{63}$ In the beginning, the Qarakhanids probably obtained tea from Tibetan merchants. Later they could also get it from the Tanguts, who received tea from the Song as diplomatic gifts and as part of their annual tribute. ${ }^{64}$ At the same time, the Qarakhanids managed to establish a direct tea trade with the Song. ${ }^{65}$ Descriptions of tea began to appear in Central Asian sources of the eleventh century. For instance, the Ghaznavid scholar al-Birūnī gives a detailed account of Chinese tea in his work Kitāb al-șaydana. He described different varieties of tea, which he called chăh, and pointed out that this term derived from the Chinese word for tea, which was apparently cha. He mentioned that the tea trade was controlled by the Chinese emperor and that no one was allowed to transport it without permission. ${ }^{66}$ The Qarakhanid merchants were among those who were allowed to obtain tea from China and

59 Dīwān lughāt al-Turk, trans. Auezova, 339.

6o Anya King, "Tibetan Musk and Medieval Arab Perfumery," in Islam and Tibet: Interactions along the Musk Routes, ed. Anna Akasoy, Charles Burnett, and Ronit Yoeli-Tlalim (Farnham: Ashgate, 2011), 148.

61 Kitāb al-Yamin̄ī, trans. Reynolds, 178.

62 Song shi, 490: 14154, 14156, 14158, 1161, 1163-1164.

63 Song shi, 490: 14154, 14156, 14158, 1161, 1163-1164.

64 Song shi, 490: 13985, 13987, 13989-13990, 13999.

65 Xu zizhi tongjian changbian, 290: 7088; Song huiyao jigao, Fanyi 4: 16.

66 Kitāb al-șaydana fi al-țībb, ed. and trans. Said, 105, Arabic text, 128. For more details on the Qarakhanid tea trade, see Chapter 6. 
transport it to other regions. Tea culture, a major aspect of Central Asian society, probably began during the Qarakhanid period.

Chinese records demonstrate intensive relations between the Qarakhanids and the Tsongkha kingdom in the eleventh century. What was the image of Tibet in the Islamic world during this period? The early medieval Islamic image of Tibet has been fairly well studied by Christopher Beckwith, a prominent scholar of Tibetan studies who has analyzed Arabic sources from the ninth to the twelfth centuries. ${ }^{67}$ Descriptions of Tibet in medieval Islamic geographical literature have also attracted not only historians of Tibet but also Arabists and Iranists. The most recent and comprehensive study of Arabic and Persian sources of Tibet has been done by Anna Akasoy, who has cogently pointed out that further research remains to be done in this field. ${ }^{68}$ Since a good deal of this literature has been surveyed by Beckwith and Akasoy, there is no need to do so here. However, one point must be made regarding the eleventh-twelfth century Central Asian sources: I will suggest that information of Tibet provided in Islamic works written by Central Asian authors of the eleventh and twelfth centuries may refer to the Tibetan Tsongkha kingdom.

The Qarakhanid scholar Maḥmūd al-Kāshgharī provided a short description of Tibetans, saying that they were a tribe in the land of Turks and produced musk. He also mentioned a famous story about the origin of the Tibetan Empire about a person from Yemen, who was forced to flee his country and came to China by sea roads. His descendants settled in a territory between China in the east, Kashmir in the west, the Uyghurs in the north, and the Indian Sea in the south. Maḥmūd al-Kāshgharī pointed out that the Tibetans of his description were descendants of people from Yemen and therefore continued to use some Arabic words in their language. ${ }^{69} \mathrm{He}$ provided this legend in order to specify their connection with the Tibetan Empire and explain the presence of Arabic words in the Tibetan language. Chinese sources also confirm that the founder of the Tsongkha kingdom was from the royal family of the former Tibetan Empire. ${ }^{70}$ Therefore, I assume that this description of Tibet refers to Tsongkha, one of the main trade partners of the Qarakhanids in the east and probably the only polity in Tibet that had diplomatic contacts with them.

\footnotetext{
67 Beckwith, The Location and Population of Tibet, 163-170.

68 Akasoy, "Tibet in Islamic Geography," 41. For general sources of Tibet from the medieval Tibetan Empire to the beginning of Tibetan modernity, see also Kurtis R. Schaeffer et al., eds., Sources of Tibetan Tradition (New York: Columbia University Press, 2013).

69 Dìwān lughāt al-Turk, trans. Auezova, 339. For the Yemen story also, see Hansgerd Göckenjan, and István Zimonyi, Orientalische Berichte über die Völker Osteuropas und Zentralasiens im Mittelalter: Die Gayhani-Tradition (Ibn Rusta, Gardizi, Hudud Al-'Alam, Al-Bakri und Al-Marwazi) (Wiesbaden: Harrassowitz, 2001), 128-131. 
Information on Tibet in Islamic literature collected during the Tibetan Empire continued to be in use in later periods despite its irrelevance or inaccuracy. For instance, the anonymous author of the late tenth century Hudüd al-älam, which was written in Persian in present-day Afghanistan, included a description of Tibet based partly on works dating to the mid-ninth century. ${ }^{71}$ Anna Akasoy pointed out that by the twelfth century, Islamic work reflects better cartographic and ethnographic knowledge of Tibet than earlier sources and suggested that local merchants might have been involved in the generation of this information. ${ }^{72}$ For instance, Marwazi provided more detailed data on Tibetan groupes, language, and customs. It is true that he mostly repeated geographical information on Tibet depicted in Hudüd al-âlam. However, he also added some new details concerning the place known as Bāb al-Tubbatayn (The Gate of the Two Tibet) where the Tibetans had a military post and collected taxes from travelers in the amount of one part out of forty. ${ }^{73}$

Another earlier example is a description of Tibet written by the Ghaznavid scholar al-Bīrūnī, who in his pharmacological work Kitāb al-șaydana provided better ethnographical knowledge of Tibet than earlier authors. It described the drinking habits of the Tibetans. He recorded that the Tibetans regularly drank significant quantities of wine and used Chinese tea as a medicine for countering the effects of alcohol. He also pointed out that his informant was a person who had traveled to China. ${ }^{74}$ Therefore, it can be concluded that al-Bīrūnī's account of Tibet, despite being very brief, is more relevant and accurate.

It is clear that only informants who had personally traveled to Tibet could provide these very detailed descriptions. I believe that Qarakhanid ambassadors and merchants actively participated in the creation of the new image of Tibet as well as China in the eleventh and twelfth centuries. Diplomatic and trade relations between the Qarakhanids and the Tsongkha kingdom might also have caused waves of migrations from Tibet to the Qarakhanid realm. For instance, Ibn al-Athīr recorded that many Turks left Tibet in 1046/47 and sent an envoy to the ruler of Balasaghun Arslan Khan to express gratitude for his kindness towards them. Arslan Khan asked them to convert to Islam. They refused, but remained in the Qarakhanid territory. ${ }^{75}$ It can be concluded that a comprehensive analysis of Tibet in the Islamic literature of this period may

$71 \quad$ Hudüd al-'alam, 92-94, 254-263. For the discussion of the anachronistic information of Tibet in this work, see Schaeffer, Sources of Tibetan Tradition, 27.

72 Akasoy, "Tibet in Islamic Geography," 33, 36, 40.

73 Tabā'i al-hayawān, ed. and trans. Minorsky, 28.

74 Kitāb al-șaydana fì al-țībb, ed. and trans. Said, 105, Arabic text, 128.

75 Al-Kāmil fì al-ta'rīkh, ed. Tornberg, vol. 9, 345; Al-Kāmil fì al-tärīkh, trans. Bulgakov and Kamoliddin, 213. 
provide more details about Tsongkha and therefore, it is a task that remains to be done.

In 1099 the Song started their occupation of Tsongkha, ${ }^{76}$ which caused a decrease in missions from the Qarkhanids. During the Song-Tsongkha conflict in 1099-1115 until the Jurchen conquest of present-day Kaifeng in 1126 and the end of the Northern Song, only six missions from the Qarakhanids came to the Chinese court. ${ }^{77}$ Tsongkha was included in the Jurchen Empire in 1182 and the last mission from Tibet (Tubo) arrived in Song China in $1136 .{ }^{78}$ Chinese sources do not mention missions from Khotan during the Southern Song.

The Qarakhanids' relations with the Khitans and the Tanguts, who sought to control trade roads to Song China, were not always peaceful. Therefore, Qarakhanid diplomacy in the East was primarily focused on finding alternative roads to the Northern Song. The Qarakhanids' main allies in the east were the Uyghur Khaganates located in Turfan and Gansu, and the Tsongkha kingdom in Tibet, which supported them in achieving their goals and establish diplomatic and commercial contacts with Liao and Song China.

The Xizhou Uyghurs played a significant role in Qarakhanid-Khitan relations. The Ganzhou Uyghurs that controlled the Hexi Corridor at the beginning of the eleventh century provided access to Song China. Later, when the road via Gansu became nearly inaccessible due to the Tangut conquest and the Song-Tangut confrontation, the Qarakhanids managed to find the alternative road via Tibet through their trade partners in Tsongkha.

The Tsongkha kingdom provided interpreters for Qarakhanid ambassadors who guided them to China. Diplomacy and trade between the Qarakhanid Khaganate and the Tsongkha kingdom resulted in greater knowledge about Tibet in the Islamic world. As we have already seen from several accounts written by Central Asian authors, who recorded new and more accurate information about Tibet, it can be concluded that due to the Qarakhanid-Tsongkha contacts and Qarakhanid activities in Tea and Horse trade along the Qinghai Road, Islamic geography was better developed by the eleventh and twelfth centuries.

76 Petech, "Tibetan Relations," 178.

77 Xu Zizhi tongjian changbian, 335: 8o61; Song shi, 49o: 14109; Song huiyao jigao, Fanyi 4: 17; also see Appendix 3 .

78 Petech, “Tibetan Relations," 178. 